\title{
SISTEM SIRKULASI AIR PADA TEKNIK BUDIDAYA BIOFLOK MENGGUNAKAN MIKROKONTROLER ARDUINO UNO R3
}

\author{
Tri Widodo,"1), Bambang Irawan²), Agung Tri Prastowo ${ }^{3)}$, Ade Surahman ${ }^{4)}$ \\ 1,2,3,4) Program Studi Teknik Komputer, Fakultas Teknik dan Ilmu Komputer, Universitas Teknokrat Indonesia \\ Jl. ZA. Pagar Alam No.9 -11, Labuhan Ratu, Bandar Lampung, Indonesia 35132 \\ Email1: 'tri_widodo@teknokrat.ac.id
}

\begin{abstract}
Biofloc technology is a cultivation technology based on the principle of inorganic nitrogen assimilation (ammonia, nitrite and nitrate) by microbial communities (heterotrophic bacteria) in a culture medium which can then be utilized by aquatic organisms as a food source. In biofloc circulation cultivation, farmers usually turn on the aerator engine as an oxygen supplier for 24 hours. Due to the absence of a water pumping machine to circulate and clean up impurities in a pond, this results in the farmer having to do the drainage of pond water manually. With the sensor and microcontroller, it makes it easier for researchers to make an automatic water circulation device. Using the turbility sensor as an indicator of water turbidity and a water pump that functions to flow through the water circulation will work according to the level of turbidity of the water.
\end{abstract}

Keywords: aerator, biofloc, microcontroller, turbidity sensor

\section{Abstrak}

Teknologi bioflok merupakan teknologi budidaya yang didasarkan pada prinsip asimilasi nitrogen anorganik (amonia, nitrit dan nitrat) oleh komunita mikroba (bakteri heterotrof) dalam media budidaya yang kemudian dapat dimanfaatkan oleh organisme budidaya sebagai sumber makanan. Pada budidaya sirkulasi bioflok, biasanya pembudidaya akan menghidupkan mesin aerator sebagai penyuplay oksigen selama 24 jam. Karena tidak adanya mesin pompa air untuk melakukan sirkulasi dan pembersihan kotoran pada kolam maka hal ini mengakibatkan pembudidaya harus melakukan pembuangan air kolam secara manual. Dengan adanya sensor dan mikrokontroler, mempermudah peneliti untuk membuat alat sirkulasi air otomatis. Dengan menggunakan sensor turbility sebagai indicator kekeruhan air dan Pompa air yang berfungsi untuk mengaliri sirkulasi air akan bekerja sesuai dengan tingkat kekeruhan air.

Kata Kunci: aerator, bioflok, mikrokontroler, sensor turbidity

\section{Pendahuluan}

Teknologi bioflok merupakan teknologi budidaya yang didasarkan pada prinsip asimilasi nitrogen anorganik (amonia, nitrit dan nitrat) oleh komunitas mikroba (bakteri heterotrof) dalam media budidaya yang kemudian dapat dimanfaatkan oleh organisme budidaya sebagai sumber makanan [1]. Budidaya ikan membutuhkan pakan sebagai penunjang pertumbuhan ikan. Pakan yang diberikan tidak semua termakan sebagian pakan yang berikan hanya $25 \%$ yang dikonversi sebagai hasil produksi dan yang lainnya terbuang sebagai limbah (62\% berupa bahan terlarut dan $13 \%$ berupa partikel terendap) [2].

Ikan nila dipilih sebagai komoditas lanjutan sistem bioflok, karena nila termasuk kelompok herbivora. Sehingga proses pembesarannya lebih cepat. Ikan nila juga mampu mencerna flok yang tersusun atas berbagai mikroorganisme, yaitu bakteri, algae, zooplankton, fitoplankton, dan bahan organik sebagai bagian sumber pakannya. Itu menguntungkan dalam budidaya di kolam bioflok.

Dalam penerapan pengolahan limbah, bahan organik berupa limbah lumpur harus terus diaduk dan diaerasi. Tujuannya adalah agar limbah selalu dalam kondisi tersuspensi sehingga dapat diuraikan oleh bakteri heterotrof secara aerobic menjadi senyawa anorganik. Keharusan pengadukan dalam teknologi pengolahan limbah ini dikarenakan jika bahan organik mengendap, maka akan terjadi kondisi yang anaerob dimana bakteri anaerob terangsang untuk mengurai bahan organik menjadi senyawa yang lebih sederhana dan bersifat racun (ammonia, nitrit, H2S, dan metana).

Pada budidaya sirkulasi bioflok, biasanya pembudidaya akan menghidupkan mesin aerator sebagai penyuplai oksigen selama 24 jam. Karena tidak adanya mesin pompa air untuk melakukan sirkulasi dan pembersihan kotoran pada kolam maka hal ini mengakibatkan pembudidaya harus melakukan pembuangan air kolam secara manual. Dengan adanya sensor dan mikrokontroler, mempermudah untuk membuat suatu alat yang bersifat otomatis [3] dengan memanfaatkan kemajuan teknologi [4][5][6]. Pada penelitian ini, digunakan sensor turbility sebagai indikator kekeruhan air dan Pompa air yang berfungsi untuk mengaliri sirkulasi air akan bekerja sesuai dengan tingkat kekeruhan air. Supaya program ini dapat berfungsi sesuai 
dengan keinginan, maka diperlukan mikrokontroler Arduino UNO R3 [7]. Sehingga alat ini bisa diprogram untuk melakukan sirkulasi air berdasarkan perintah yang telah ditentukan.

\section{Metode}

\section{A. Sirkulasi}

Istilah sirkulasi ini dikenal dengan pergantian air pada kolam atau akuarium ataupun media perairan yang terbatas dan teratasi sebanyak 10 sampai $50 \%$ volume awal. Secara sederhana, sirkulasi berarti pergantian air pada kolam sebanyak (baiknya) 10\%-30\% dari volume air semula, tujuannya untuk memperbaiki kualitas air.

B. Teknologi Bioflok

Bioflok diartikan sebagai sekumpulan dari beberapa mikroorganisme yang menyatu karena adanya ikatan yang disebut biopolymer. Bioflok terdiri dari algae, yeast, plankton, protozoa dan beberapa hewan renik lainnya seperti cacing dan lain-lain. Bioflok terbentuk oleh bermacam-macam organisme, dengan adanya bakteri dalam bioflok maka proses degradasi bahan organik akan lancar, sehingga menghasilkan zat-zat yang bermanfaat bagi pertumbuhan plankton [8]. Komposisi bioflok dalam kadar berat kering mengandung protein sebesar 38\%, lemak $3 \%$, serat $6 \%$, abu $12 \%$ dan energi $19 \mathrm{~kJ} / \mathrm{g}$.

Teknologi bioflok merupakan salah satu alternatif baru dalam mengatasi masalah kualitas air dalam akuakultur yang diadaptasi dari teknik pengolahan limbah domestik secara konvensional [8]. Prinsip utama yang diterapkan dalam teknologi ini adalah manajemen kualitas air yang didasarkan pada kemampuan bakteri heterotrof untuk memanfaatkan $\mathrm{N}$ organik dan anorganik yang terdapat di dalam air.

Tujuan utama teknologi bioflok dalam budidaya perairan adalah memanfaatkan nitrogen anorganik dalam kolam budidaya menjadi nitrogen organik yang tidak bersifat toksik. Sistem bioflok dalam budidaya menekankan pada pertumbuhan bakteri pada kolam untuk menggantikan komunitas autotrofik yang didominasi oleh fitoplankton. Dominasi bakteri dalam suatu sistem dipengaruhi oleh rasio $\mathrm{C} / \mathrm{N}$ media. Bioflok akan terbentuk jika rasio $\mathrm{C} / \mathrm{N}$ dalam kolam budidaya lebih dari 15 [8].

\section{Ikan Nila}

Ikan nila memiliki bentuk tubuh pipih memanjang ke samping. Mempunyai garis vertikal 9-11 buah berwarna hijau kebiruan. Pada sirip ekor terdapat 6-12 garis melintang yang ujungnya berwarna kemerahmerahan, sedangkan pada punggungnya terdapat garisgaris miring. Mata tampak menonjol agak besar dengan bagian tepi berwarna hijau kebiru-biruan. Letak mulut ikan nila terminal, posisi sirip perut terhadap sirip dada thorochis, gurat sisi (linea lateralis) terputus menjadi dua bagian. Jumlah sisik pada gurat sisi 34 buah dan tipe sisik stenoid. Bentuk sirip ekor berpinggiran tegak [9].

Ikan nila mempunyai habitat di perairan tawar, seperti sungai, danau, waduk dan rawa. Tetapi karena toleransinya yang tinggi terhadap salinitas, maka ikan dapat hidup dan berkembang biak di perairan payau dan laut. Salinitas yang disukai antara 0 - 35 ppt. Ikan nila yang masih kecil lebih tahan terhadap perubahan lingkungan dibanding dengan ikan yang sudah besar. Kualitas air yang sesuai dengan habitat ikan nila adalah $\mathrm{pH}$ optimal antara 7 - 8, suhu optimal antara $25-30^{\circ} \mathrm{C}$, dan salinitas 0 - $35 \mathrm{ppt}$, amonia antara $0-2.4 \mathrm{ppm}$, dan DO berkisar antara 3 - 5 ppm.

D. Alat

Penelitian ini dilakukan menggunakan perangkat keras dan perangkat lunak sebagai berikut:

1. Filtrasi, berfungsi sebagai penyaringan air olahan yang mengandung padatan dengan ukuran seragam menggunakan saringan medium tunggal, sedangkan untuk penyaringan air yang mengandung padatan dengan ukuran yang berbeda dapat digunakan tipe saringan multi medium.

2. Arduino UNO, board berbasis mikrokontroler pada ATmega328 [10]. Board ini memiliki 14 digital input/output pin (dimana 6 pin dapat digunakan sebagai output PWM), 6 input analog, $16 \mathrm{MHz}$ osilator kristal, koneksi USB, jack listrik tombol reset. Pin-pin ini berisi semua yang diperlukan untuk mendukung mikrokontroler, hanya terhubung ke komputer dengan kabel USB atau sumber tegangan bisa didapat dari adaptor AC-DC atau baterai untuk menggunakannya [11]. ATmega328 pada Arduino UNO hadir dengan sebuah bootloader yang memungkinkan kita untuk mengupload kode baru ke ATmega328 tanpa menggunakan pemrogram hardware eksternal [12].

3. Liquid Crystal Display (LCD), difungsikan untuk menampilkan suhu, kelembaban dan mode sistem yang sedang berjalan [13]. Dalam modul LCD terdapat mikrokontroler yang berfungsi sebagai pengendali tampilan karakter LCD. Mikrokontroler pada suatu LCD dilengkapi dengan memori dan register [14].

4. Motor AC (Water Pump), digunakan sebagai motor pompa yang dapat mengalirkan air, dengan cara menghisap air melalui lubang dibagian bawah dan mengalirkanya ke samping, sehingga akan dihasilkan suatu aliran air dengan kecepatan tertentu [15].

5. Aerator, alat yang membantu melarutkan oksigen yang ada di udara ke dalam air kolam atau aquarium. Prinsip kerja alat ini adalah membuat permukaan air sebanyak mungkin bersentuhan dengan udara. Tujuannya adalah agar kandungan oksigen dalam air itu cukup dan gas serta zat yang biasanya menimbulkan bau busuk dapat terusir dari air. Aerator ini membuat gelembunggelembungudara di dalam air. Besar kecilnya udara dapat diatur. Gelembung udara itu menyebabkan permukaan air yang bersentuhan dengan udara menjadi lebih luas. Waktu gelembung udara itu mengapung ke atas dan pecah di permukaan, permukaan air bergoyang sehingga kapasitasnya untuk menyerap oksigen dari udara juga menjadi bertambah.

6. Sensor Kejernihan Air, salah satu alat umum yang biasa digunakan untuk keperluan analisa kekeruhan air atau larutan. Turbidity meter merupakan alat pengujian kekeruhan dengan sifat optik akibat 
dispersi sinar dan dapat dinyatakan sebagai perbandingan cahaya yang dipantulkan terhadap cahaya yang datang. Intensitas cahaya yang dipantulkan oleh suatu suspensi padatan adalah fungsi konsentrasi jika kondisi-kondisi lainnya konstan. Alat ini banyak digunakan dalam pengolahan air bersih untuk memastikan bahwa air yang akan digunakan memiliki kualitas yang baik dilihat dari tingkat kekeruhanya [16].

7. Jumper Wire, kabel yang biasanya digunakan untuk penghubung antara perangkat sensor ataupun breadbord dengan mikrokontroler dan media transmisi penghantar listrik maupun sinyaal-sinyal dari sensor, kemudian diterjemahkan oleh mikrokontroler itu sendiri. Secara umum jumper wire terdiri dari 3 jenis, yaitu: male-male, male-female, female-female.

8. Adaptor $12 \mathrm{~V}$, digunakan untuk menurunkan tegangan AC 22 Volt menjadi kecil antara 3 volt sampai 12 volt. Terdapat 2 jenis adaptor berdasarkan sistem kerjanya, adaptor sistem trafo step down dan adaptor sistem switching.

9. Switch Button, saklar tekan yang berfungsi untuk menghubungkan atau memisahkan bagian-bagian dari suatu instalasi listrik satu sama lain (suatu sistem saklar tekan push button terdiri dari saklar tekan start, stop reset dan saklar tekan untuk emergency. Switch Push memiliki kontak NC (normally close) dan NO (normally open) [17]. Push button switch adalah perangkat/saklar sederhana yang berfungsi untuk menghubungkan atau memutuskan aliran arus listrik dengan sistem kerja tekan unlock (tidak mengunci). Sistem kerja unlock disini berarti saklar akan bekerja sebagai device penghubung atau pemutus aliran arus listrik saat tombol ditekan, dan saat tombol tidak ditekan (dilepas), maka saklar akan kembali pada kondisi normal [18].

D. Tahapan Penelitian

Penelitian yang dilakukan mencakup beberapa tahapan yaitu, perancangan diagram blok, perancangan keseluruhan alat, pecancangan sensor turbidity, perancangan LCD, perancangan relay, dan penggunaan software Arduino IDE. Berikut penjelasan dari setiap tahapan yang dilakukan:

1. Perancangan diagram blok, pada Gambar 1 ditampilkan diagram blok ayng menjelaskan tentang cara kerja alat secara keseluruhan mulai dari input, proses, hingga output. Dalam diagram blok ini hanya terdapat hubungan jalur antara blok-blok saja, tetapi tiap masing-masing blok terdapat komponen utama dan komponen pendukung.

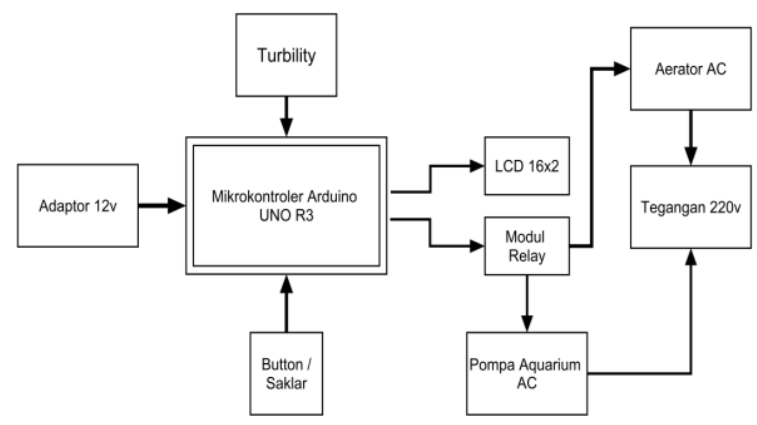

Gambar 1. Blok diagram sistem sirkulasi air

Dari blok diagram di atas dapat dijelaskan fungsi masing-masing blok sebagai berikut :

- Adaptor $12 \mathrm{~V}$ digunakan untuk memberikan tegangan ke arduino dan komponen lainnya yang terhubung ke arduino.

- Mikrokontroler Arduino digunakan untuk mengontrol semua komponen baik itu komponen input dan komponen output.

- Sensor turbidity digunakan sebagai indikator kejernihan air untuk mengontrol pompa dan aerator.

- LCD 16x2 digunakan sebagai monitor yang akan menapilkan nilai dari sensor turbidity.

- Modul Relay digunakan sebagai saklar otomatis untuk menghidupkan dan mematikan pompa air dan aerator.

- Switch Button / Saklar digunakan untuk menghidupkan modul relay yang terhubung ke pompa air secara manual.

- Pompa air digunakan untuk sirkulasi yang akan hidup sesuai dengan waktu yang ditentukan.

- Aerator digunakan untuk menghasilkan oksigen yang akan hidup sesuai dengan waktu yang ditentukan

2. Perancangan keseluruhan alat, terdiri dari empat elemen penting yang saling terintegrasi. Elemenelemen penting tersebut yaitu rangkaian input, rangkaian pengendali, rangkaian output dan juga software program yang saling terintegrasikan. Rangkaian yang terdiri dari komponen-komponen elektronika baik berupa input atau output yang dibutuhkan oleh mikrokontroler agar dapat berfungsi dengan baik. Rangkaian keseluruhan alat dapat dilihat pada Gambar 2.

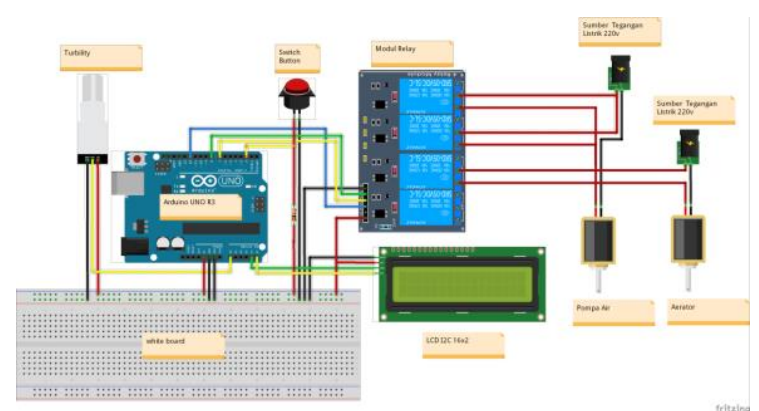

Gambar 2. Rangkaian keseluruhan alat

Dari rangakaian keseluruhan alat diatas dapat 
dijelaskan sebagai berikut :

- Sensor turbility terdapat 3 konektor masing masing ada VCC, OUT, GND VCC ke $5 \mathrm{~V}$ Arduino, OUT ke A0, GND ke GND Arduino

- LCD terdapat 4 konektor masing-masing ada VCC, GND, SCL, SDA. Akan disambungkan ke pin arduino yaitu, VCC LCD dihubungkan ke $5 \mathrm{~V}$ Arduino, GND LCD dihubungkan GND Arduino, SDA dihubungkan ke pin A4 Arduino, dan SLC dihubungkan ke A5 Arduino.

- Switch button terdapat dua kaki, kaki pertama dihubungkan ke pin GND Arduino. Pin 5v Arduino dihubungkan ke salah satu kaki resistor $10 \mathrm{k} \Omega$, kemudian ujung kaki resistor satunya dihubungkan ke pin 2 Arduino dan dihubungkan ke kaki kedua switch button.

- Modul relay terdapat 4 konektor yang dihubungkan ke pin Arduino. Pin 5v Arduino dihubungkan ke VCC relay, pin GND Arduino dihubungkan ke GND relay, pin 7, 8 dan 12 Arduino dihubungkan ke IN1, IN2 dan IN3 relay.

- Pompa aquarium akan dihubungkan ke modul relay, salah satu kabel pompa akan diputus dan bagian kabel kearah pompa dihubungkan ke pin 3 dan 6 pada channel modul relay. Kemudian kabel kearah listrik dihubungkan ke pin 2 dan 5 pada channel modul relay.

- Aerator akan dihubungkan ke modul relay, salah satu kabel aerator akan diputus dan bagian kabel kearah aerator dihubungkan ke pin 9 pada channel modul relay. Kemudian kabel kearah listrik dihubungkan ke pin 8 pada channel modul relay.

3. Perancangan sensor turbidity, perancangan salah satu alat umum yang biasa digunakan untuk keperluan analisa kekeruhan air atau larutan. Turbidity meter merupakan alat pengujian kekeruan dengan sifat optik akibat dispersi sinar dan dapat dinyatakan sebagai perbandingan cahaya yang dipantulkan terhadap cahaya yang datang. Intensitas cahaya yang dipantulkan oleh suatu suspensi padatan adalah fungsi konsentrasi jika kondisi-kondisi lainnya konstan. Alat ini banyak digunakan dalam pengolahan air bersih untuk memastikan bahwa air yang akan digunakan memiliki kualitas yang baik dilihat dari tingkat kekeruhanya. Skematik rancangan sensor turbidity ditunjukkan pada Gambar 3.

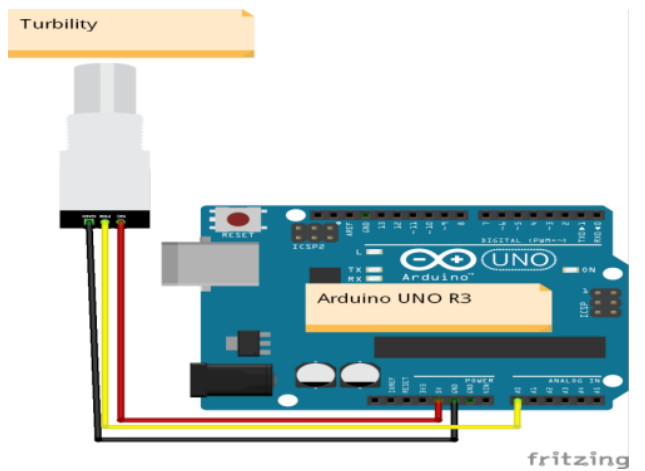

Gambar 3. Skematik rancangan sensor turbidity
4. Perancangan LCD, difungsikan untuk menampilkan data tanggal dan waktu untuk memonitor alat yang bekerja secara real time. Skematik rancangan LCD ditunjukkan pada Gambar 4.

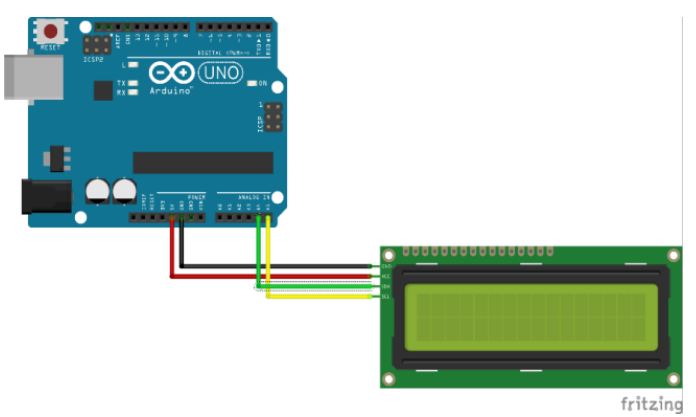

Gambar 4. Skematik rancangan LCD

5. Perancangan relay, digunakan untuk dioperasikan secara listrik dan relay ini digunakan sebagai saklar untuk menghidupkan pompa air dan aerator yang ada di dalam perancangan alat ini. Skematik rancangan LCD ditunjukkan pada Gambar 5.

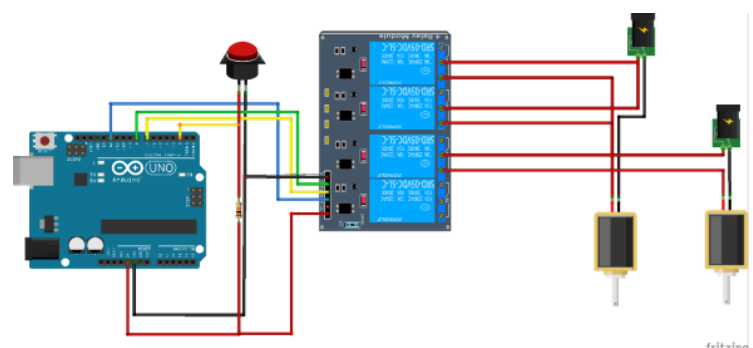

Gambar 5. Skematik rancangan relay

6. Penggunaan software Arduino IDE, dilakukan untuk memberikan instruksi-instruksi menggunkan bahasa pemrograman $\mathrm{C}$ yang bertujuan untuk menjalankan sistem agar dapat berkerja sesuai kode program yang telah diisikan kedalam sebuah Arduino. Berikut contoh tampilan penulisan kode program yang ditunjukkan pada Gambar 6.

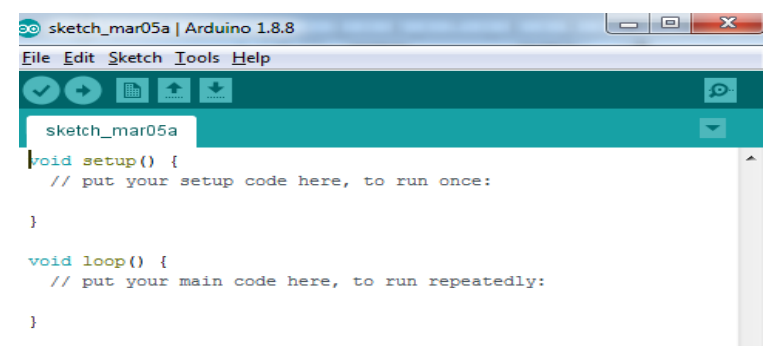

Gambar 6. Layer untuk penulisan sketch pada program Arduino IDE

\section{Hasil dan Pembahasan}

Sistem sirkulasi air pada teknik budidaya bioflok dibangun menggunakan alat mikrokontroller Arduino R3, LCD 16*2 \& LED, sensor turbidity, relay, adaptor, pompa, button. Tampilan dari alat yang dibangun dapat dilihat pada Gambar 7 dan Gambar 8. 


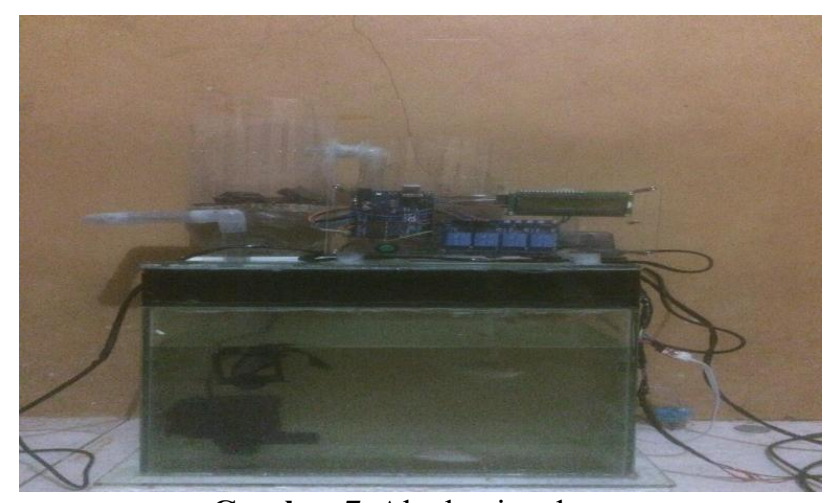

Gambar 7. Alat bagian depan

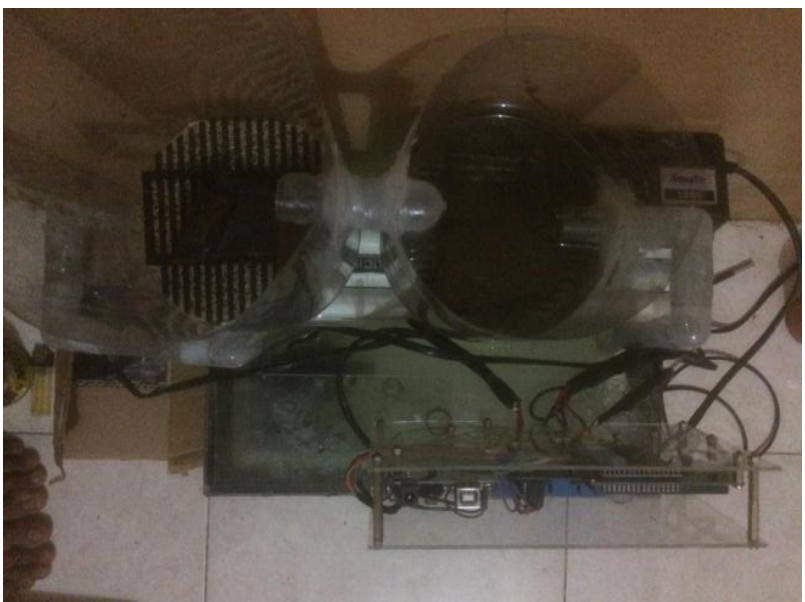

Gambar 8. Alat bagian atas

A. Alur Proses

Secara umum, alat yang dibangun memiliki memiliki alur proses seperti ditunjukkan pada Gambar 9.

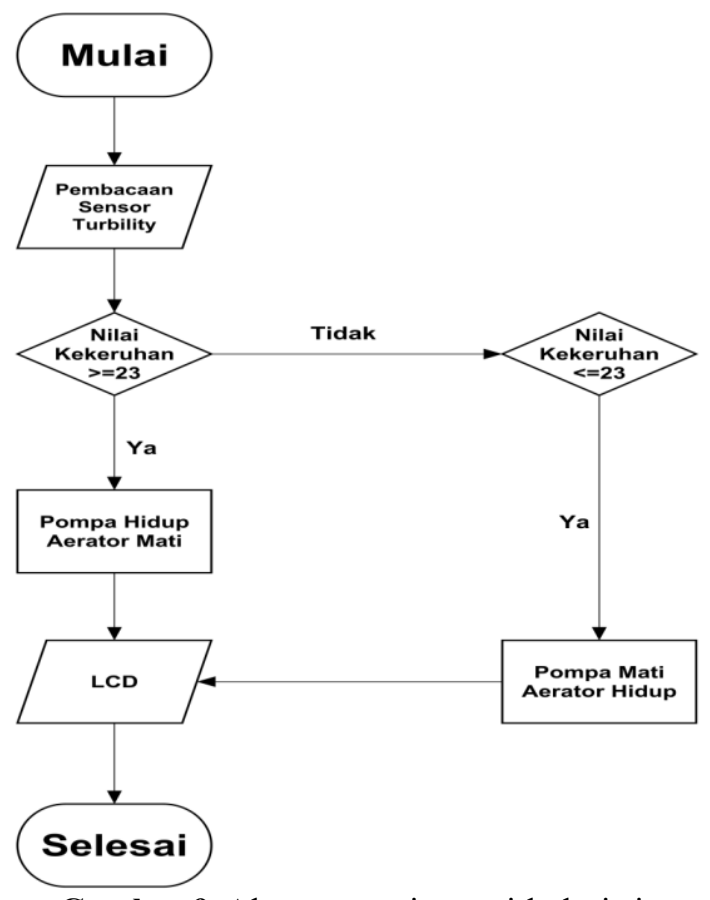

Gambar 9. Alur proses sistem sirkulasi air
1. Pada awal sistem mulai mempersiapkan inisialisasi sensor turbidity membaca.

2. Sensor turbility akan memberikan data sesuai perintah dari Arduino.

3. Kemudian sensor turbility yang sudah diberikan perintah kejernihan air dengaan nilai >23 mengirim data ke Arduino untuk mengatur modul relay yang berfungsi menghidupkan pompa air dan aerator mati.

4. Jika kejernihan air <23 maka pompa mati aerator hidup

B. Pengujian

Tujuan pengujian mikrokontroler pada alat ini yaitu untuk menentukan apakah alat yang telah dibuat berfungsi dengan baik dan sudah sesuai dengan perancangan atau belum. Pengujian pada alat ini meliputi pengujian setiap blok maupun pengujian secara keseluruhan. Pengujian setiap blok ini dilakukan untuk menentukan letak kesalahan dan mempermudah dalam analisa mikrokontroler bila alat tidak bekerja sesuai rancangan.

1. Pengujian komponen, mula-mula pengujian dilakukan dengan terpisah, mulai dari komponenkomponen yang digunakan dalam perancangan alat ini sehingga mendapatkan hasil yang diinginkan. Setelah itu pengujian dilanjutkan dengan pengujian dari keseluruhan rangkaian komponen mikrokontroler yang telah terpasang.

2. Pengujian LCD, modul LCD $16 \times 2$ telah berhasil digunakan sebagai monitor untuk mengetahui kondisi kerja sistem pemantauan lebih mudah, serta dapat melihat jadwal pompa $O N$ dan pompa $O F F$ yang akan ditampilkan pada LCD.

3. Pengujian sendor turbidity, menunjukkan keberhasilan untuk dapat digunakan mengontrol kejernihan air. Sensor turbidity akan mengirimkan perintah program mengatur modul relay yang berfungsi untuk menghidupkan pompa air. Berikut hasil pengujian sensor turbidity yang tertera pada Tabel 1.

Tabel 1. Hasil pengujian sensor turbidity

\begin{tabular}{ccc} 
No & Kekeruhan & Keterangan \\
\hline 1 & $>25$ & Air keruh \\
2 & $<23$ & Air jernih \\
\hline
\end{tabular}

4. Pengujian relay, penggunaan relay berhasil dilakukan untuk mengontrol pompa, yang mana sebelum nya sudah di perintah oleh Arduino agar sesuai dengan kejernihan yang diatur. Berikut hasil pengujian relay yang ditunjukkan pada Tabel 2 .

Tabel 2. Hasil pengujian relay

\begin{tabular}{ccc} 
No & Kekeruhan & Keterangan \\
\hline 1 & $>25$ & $\begin{array}{c}\text { Pompa } O N, \\
\text { aerator } O F F\end{array}$ \\
2 & $<23$ & $\begin{array}{c}\text { Pompa } O F F, \\
\text { aerator } O N\end{array}$ \\
\hline
\end{tabular}

Berikut penjelasan lengkapnya dari Gambar 9: 
5. Pengujian water pump, merupakan hasil akhir dari keseluruhan alat yang telah melalui serangkaian perintah, pompa akan hidup apabila sensor turbility membaca kejernihan air.

\section{Kesimpulan dan Saran}

Berdasarkan hasil pengujian dan analisi alat secara lengkap, dapat diambil kesimpulan sebagai berikut: 1) Telah berhasil dibuat sebuah sistem otomatis pada bioflok yang dapat mengatur kejernihan air dengan menggunakan sensor turbidity; 2) Sistem sirkulasi air dalam bioflok, yang mengunakan sensor turbidity dapat mengetahui kejernihan air; 3) Metode pengaturan sirkulasi otomatis pada bioflok, terbukti lebih efektif dan hemat air, dibandingkan dengan metode sirkulasi yang belum otomatis dalam mengatur hidup dan mati pompa; 4) Keseluruhan sistem yang terdiri dari Arduino UNO, sensor turbidity, relay, pompa air, push button dan penampil LCD $16 \times 2$ dapat bekerja dan berintegrasi dengan baik; 5) Sistem otomasi bioflok dapat memberikan kemudahan dalam menjalankan suatu sistem serta dapat menjadi alternatif dalam budidaya ikan di lahan terbatas.

Penelitian ini masih bisa dikembangkan untuk kedepannya, adapun saran yang dapat diberikan yaitu sebagai berikut: 1) Dapat di tambahkan dengan alat lain, seperti pemberian pakan otomatis untuk ikan maupun sistem lain yang akan menunjang sistem bioflok lebih kompleks lagi; 2) Sistem dapat di tambahkan suatu sensor asam basa (sensor $\mathrm{pH}$ ) pada air kolam bioflok, sehingga dapat diketahui nilai pH yang baik bagi air kolam; 3) Perancangan Sistem yang dibuat adalah bentuk sistem yang dapat di manfaatkan maupun dirubah kedalam bentuk sistem yang lain, tidak terpaku hanya pada bioflok saja.

\section{Daftar Pustaka}

[1] Y. Rahmanto, A. Rifaini, S. Samsugi, and S. D. Riskiono, "Sistem Monitoring $\mathrm{pH}$ Air Pada Aquaponik Menggunakan Mikrokontroler Arduino UNO," J. Teknol. dan Sist. Tertanam, vol. 1, no. 1, pp. 23-28, 2020.

[2] M. F. Suryaningrum, 2012, “Aplikasi Teknologi Bioflok pada Pemeliharaan BenihIkan Nila (Oreochromis nilotics)," Jakarta: Universitas Terbuka.

[3] S. Samsugi, Z. Mardiyansyah, and A. Nurkholis, "Sistem Pengontrol Irigasi Otomatis Menggunakan Mikrokontroler Arduino UNO," J. Teknol. dan Sist. Tertanam, vol. 1, no. 1, pp. 17-22, 2020.

[4] A. Nurkholis, A. Riyantomo dan M. Tafrikan, "Sistem pakar penyakit lambung menggunakan metode forward chaining," Majalah Ilmiah Momentum, vol. 13, no. 1, 2017.

[5] A. Nurkholis and I. S. Sitanggang, "Optimalisasi model prediksi kesesuaian lahan kelapa sawit menggunakan algoritme pohon keputusan spasial," J. Teknol. dan Sist. Komput., vol. 8, no. 3, pp. 192200, 2020, doi: 10.14710/jtsiskom.2020.13657.

[6] A. Nurkholis and I. S. Sitanggang, "A spatial analysis of soybean land suitability using spatial decision tree algorithm," in Sixth International Symposium on LAPAN-IPB Satellite, Dec. 2019, no. December, p. 113720I, doi: 10.1117/12.2541555.

[7] A. P. Zanofa, R. Arrahman, M. Bakri, and A. Budiman, "Pintu Gerbang Otomatis Berbasis Mikrokontroler Arduino UNO R3," J. Tek. dan Sist. Komput., vol. 1, no. 1, pp. 22-27, 2020.

[8] Avnimelech, 2009, "A Practical Guide Book. World," Louisiana, USA: Aquaculture Society.

[9] Kordi, 2010. "Pintar Budidaya Ikan di Tambak Secara Intensif," Yogyakarta: Andi.

[10] Y. Rahmanto, A. Rifaini, S. Samsugi, and S. D. Riskiono, "Sistem Monitoring $\mathrm{pH}$ Air Pada Aquaponik Menggunakan Mikrokontroler Arduino UNO," J. Teknol. dan Sist. Tertanam, vol. 1, no. 1, pp. 23-28, 2020.

[11] Z. N. Saputri and M. Rif'an, "Aplikasi Pengenalan Suara Sebagai Pengendali Peralatan Listrik Berbasis Arduino UNO," Jurnal Mahasiswa TEUB, vol. 2, no. 5, 2014.

[12] M. Ichwan, "Pembangunan prototipe sistem pengendalian peralatan listrik pada platform android," Jurnal informatika, 2013.

[13] I. K. Gunawan, A. Nurkholis, and A. Sucipto, "Sistem Monitoring Kelembaban Gabah Padi Berbasis Arduino," J. Tek. dan Sist. Komput., vol. 1, no. 1, pp. 1-7, 2020.

[14] A. Anantama, A. Apriyantina, S. Samsugi, and F. Rossi, "Alat Pantau Jumlah Pemakaian Daya Listrik Pada Alat Elektronik Berbasis Arduino UNO," $J$. Teknol. dan Sist. Tertanam, vol. 1, no. 1, pp. 29-34, 2020.

[15] B. Santoso and A. D. Arfianto, "Sistem pengganti air berdasarkan kekeruhan dan pemberi pakan ikan pada akuarium air tawar secara otomatis berbasis mikrokontroler atmega 16," Jurnal Ilmiah Teknologi dan Informasi ASIA, vol. 8, no. 2, 2014.

[16] A. T. Wahyudi, Y. W. Hutama, M. Bakri, and S. D, Riskiono, "Sistem Otomatis Pemberian Air Minum Pada Ayam Pedaging Menggunakan Mikrokontroller Arduino dan RTC DS1302," J. Tek. dan Sist. Komput., vol. 1, no. 1, pp. 22-28, 2020.

[17] M. Kurniasih and A. Achmad, "Simulasi Monitoring Dosen Menggunakan Switch Push ON Pada Laboratorium Komputer Univeritas Budi Luhur," Jurnal Ilmiah Komputer dan Informatika, vol. 5, no. $1,2016$.

[18] S. J. Sokop, D. J. Mamahit and S. R. Sompie, "Trainer Periferal Antarmuka Berbasis Mikrokontroler Arduino Uno," Jurnal Teknik Elektro dan Komputer, vol. 5, no. 3, pp.13-23, 2016. 